\title{
Assessing the effectiveness of Covid-19 financial product innovations in supporting financially distressed firms and households in the UAE
}

\author{
Florian Gerth $^{1} \cdot$ Vikash Ramiah $^{1} \cdot$ Elissar Toufaily $^{2} \cdot$ Glenn Muschert $^{3}$
}

Received: 21 December 2020 / Revised: 16 April 2021 / Accepted: 27 April 2021 / Published online: 17 May 2021

(c) The Author(s), under exclusive licence to Springer Nature Limited 2021

\begin{abstract}
Covid-19 has affected the global economy, influencing firm and household financial decisions worldwide. The Central Bank of the United Arab Emirates (CBUAE) released an AED 256 billion stimulus package to provide banks with sufficient capital to support economic activities and development by providing temporary relief to large corporations, small- and medium-sized enterprises, and households. New financial products have rapidly appeared, including relief packages for rent, mortgages, personal loans, credit cards, SMEs, and corporate entities. Regression analysis explores the effect of such relief packages on UAE firm and household finances. Using online survey data gathered via convenience sampling of UAE households, econometric analysis confirms that select demographic factors and financial instruments positively relate to effective financial decision-making. Our results guide policymakers on which relief packages effectively manage firm-level and household financial distress during a health pandemic.
\end{abstract}

Keywords Covid-19 · Financial Recovery $\cdot$ Products Innovations $\cdot$ Relief Packages $\cdot$ Household Finance $\cdot$ Financial Planning

\section{Introduction}

As a global health and humanitarian crisis, the Covid-19 pandemic has affected society at both the macro- and micro-level (Finsterwalder and Kuppelwieser 2020), and its economic and financial effects are unprecedented. Since the onset of the outbreak, individuals and communities' psychological, physical, financial, and social challenges and the pressure on industries and the global economy have increased. Economists predict that the loss in global economic production might total around USD 3.5 trillion (Statista Research Department 2020). As the pandemic has altered the operations of firms and the lives of households and inflicted chaos on their financial decisions, the Central Bank of the United Arab Emirates (CBUAE) has launched an AED 256bn stimulus package to support the economy (KPMG 2020; UAE Government Portal 2020). The

Florian Gerth

FlorianGerth@uowdubai.ac.ae

1 University of Wollongong in Dubai, Knowledge Park, Dubai, UAE

2 American University in Dubai, Dubai, UAE

3 Khalifa University of Science and Technology, Abu Dhabi, UAE general aim of these capital and liquidity tools is to prevent a credit crunch by ensuring that financial intermediaries have sufficient capital to support economic agents during the crisis period. Banks have a requirement to pass on the benefits as temporary relief offers to the private sector. The purpose is to ease principal and interest payments on outstanding loans for stakeholders who have experienced financial trauma due to Covid-19. Consequently, new financial products have rapidly appeared, including relief packages for rent, mortgages, personal loans, credit cards, SMEs, and corporate entities. Thus, this paper aims to explore the effectiveness of such relief packages on the finances of firms and households within the UAE.

As Covid-19 is a novel virus, empirical studies investigating the behavioral and financial factors contributing to firm and household decision-making are virtually non-existent. This paper focuses on the behavior of those firms and households within the UAE exposed to extreme financial losses. To that effect, it contributes by adding to the economic and financial crisis literature by analyzing the financial strategies in coping with adverse financial shocks during severe pandemics. ${ }^{1}$

\footnotetext{
${ }^{1}$ Financial shocks refer to any expense or loss of income that firms and households do not plan for when budgeting, regardless of the extent to which the shock may harm them financially (Pew Charitable Trusts 2015).
} 
Our methodological approach consists of a survey based on questionnaire design as a data collection method of snowball sampling. Entrepreneurs, managers, experts, students, and households within the UAE responded to the questionnaire. We analyzed the collected data and estimated a set of regression models to test the statistical validity of the quantitative findings through empirical modeling. This approach helps us test the empirical significance of whether, and to which extent, fiscal and monetary policies help companies and individuals survive in deteriorating health and financial environments.

Our analysis finds that certain firms are negatively affected by disruptions to their operations and losses in business and industry premises. On the other hand, households are impaired by losses in income, equity savings instruments, and residential housing, often leading to deteriorations in mental and physical health. In terms of the effectiveness of policies meant to support the UAE economy, firms benefit from the stimulus package organized by the CBUAE, chiefly by the bank rent relief package, by the private corporate relief package, and, surprisingly, by the mortgage relief package. The latter finding emphasizes the fact that entrepreneurs try to smooth their debt cycle by using private capital. Households, in comparison, are effectively supported by the mortgage relief package, the personal loan relief package, and the bank rent relief package. These results emphasize the importance of targeted fiscal and monetary intervention during a health crisis to maintain the financial and economic survival of an economy and its stakeholders. Surprisingly and alarmingly, one of the most significant loss categories of households, losses in residential housing, is not supported by these policies.

The paper is structured as follows; Sect. "Literature review presents the literature on crisis management and covid-19 research. The following part, Sect. "Policy support", illustrates the fiscal and monetary policies to support the real and financial sector. In Sect. "Research design", we outline the research design of the study and introduce the empirical model. Section "Results and empirical evidence" discusses the results. The last section concludes.

\section{Literature review}

Disasters disrupt communities by negatively impacting the well-being of humans, the economy, or the environment (United Nations Office for Disaster Risk Reduction 2012) and turn into long-lasting and severe crises should they not be managed immediately and effectively. The novelty of Covid19 has found policymakers unprepared and raised concerns about the social, economic, and financial repercussions (Brown et al. 2020; Brown 2020; Finsterwalder and Kuppelwieser 2020). Previous research has studied the financial and psychological impact of disasters. Galea et al. (2008) find evidence for post-traumatic stress disorder following financial losses caused by natural disasters. Focusing on bushfires within Australia, Asbi et al. (2020) identified significant and long-lasting effects on business premises, residential housing, livestock, and infrastructure. To prevent permanent damage to the economic system, Zhang and Zhang (2011) study the role of fiscal policy in economic recovery. The authors find that the government can support the economy in the short run. However, in the medium run, negative side-effects might arise and therefore lead to economic deterioration in terms of fiscal (in)stability and inflationary pressures. Following this strand of literature, the purpose of our paper is to analyze the policy stance adopted by UAE policymakers and empirically determine its effectiveness in supporting firms and households in their financial survival.

Research about the consequences of Covid-19 is scarce and non-conclusive in terms of financial survival. Hall et al. (2020) evaluate changes in consumption patterns by observing spatial and temporal displacement of consumption spending. Heinonen and Strandvik (2020) draw on a crowdsourced database of 221 innovations associated with Covid-19 to analyze strategic issues related to the fragility of firms. They conclude that businesses have to implement transformations in their markets and service offerings to facilitate economic survival. From an actuarial perspective, Ritcher and Wilson (2020) analyze the changes in underwriting standards following Covid-19. They conclude that certain pandemic costs are not insurable, and the risk has to be carried by the individual to support the insurance industry. Cowling et al. (2020) research whether businesses have been increasing their cash holdings in the lead-up of the Covid-19 crisis, finding that more than $60 \%$ of small and medium-sized enterprises (SME) are on the brink to run out of cash due to insufficient cash holdings. Elnahass et al. (2021) consider 1090 banks in 116 countries worldwide and find that the Covid-19 outbreak severally shakes financial performance and stability.

On the other hand, Greene and Rosiello (2020) argue that the Covid-19 crisis might entail opportunities for firms to take a pro-active stance and re-orient their strategies for when the crisis is over. Also focusing on the opportunities arising, Pandey (2021) researches the digital marketing strategies that have evolved in the face of national and international lockdowns. Corbet et al. (2020) analyze the correlation between Chinese financial markets at the outbreak of the crisis and cryptocurrencies. The authors find that as market turmoil progressed, the correlation between both sets of assets deepened. Furthermore, Hepburn et al. (2020) argue that fiscal policy recovery packages, due to the pandemic, lead to market failure in misallocating environmental resources in the economic system. Excluding any equilibrium macro-effects, our paper extends and complements this literature by analyzing the behavior of individual firms and households during the pandemic following the pro-active stance of the UAE policymakers. 


\section{Policy support}

With the global rise in Covid-19 infections by March 2020, UAE policymakers decided to offer a range of active and passive relief packages to support the financial and real sectors of the economy (KPMG, 2020). The biggest of these relief packages is the Targeted Economic Support Scheme (TESS) organized by the CBUAE. The initial funding for the scheme was AED 100bn; however, in November 2020, it was upgraded to AED 256bn to counteract the unprecedented negative economic trajectory of the UAE economy. The total package later increased to AED256 billion. It has now been increased again by an additional AED50 billion from 1 January 2021 to 30 June 2021. TESS aims to support the UAE's economy through a range of relief measures related to funding, liquidity, financing, and capital. Its purpose is to deliver temporary relief from principal or interest payments on outstanding loans for private-sector corporations, small- and medium-sized enterprises (SMEs), and residents. As a result, several new relief packages have mushroomed, like the rent relief package, the mortgage relief package, the personal loan relief package, the credit card relief package, the SME relief package, and the private corporate relief package (KPMG 2020). The CBUAE made the new funds available to selective banks. The funds have the purpose of helping customers affected by Covid-19 who cannot repay personal or business finance. Participating banks may use the funding to offer temporary relief to retail customers for up to six months. TESS relief is not a cancellation of outstanding financial obligations but a deferral of such payments, according to the merits of each case. Individuals and businesses affected by a liquidity crunch because of Covid-19 had approached their banks directly, and decisions occurred on a case-by-case basis. The CBUAE requires banks and finance companies who have access to TESS funds to comply with the standards set by the scheme. For example, banks and finance companies could no longer (1) charge customers receiving relief under the TESS program any additional fees/penalties/interest for deferred payments; (2) increase interest rates for customers using deferrals; and (3) apply late payment fees.

According to CBUAE data (2020), over 320,000 customers had benefited from the TESS finance deferral program as of early November 2020. Of these, 310,000 were retail customers, 10,000 were small and medium enterprises, and another 1,500 were private sector corporates.

The Community Solidarity Fund Against Covid-19 is another fund launched by Dubai's Islamic Affairs and Charitable Activities Department, in coordination with the Permanent Committee for Labour Affairs. It has sponsored 172 tickets worth AED184,040 to help workers in troubled companies return to their home countries. Dubai Chamber has also donated AED10 million ( $\$ 2.7 \mathrm{~m}$ ) to the Community Solidarity Fund Against Covid-19 (Arabian Business 2020).

\section{Research design}

The quantitative survey method was adopted for data collection to achieve better representativeness of the results. The survey questionnaire design mirrored the concepts identified in the literature review. It incorporated items that had either been taken directly or adapted from previous studies on the topic of pandemics, financial crises, extreme events, financial planning, and behavioral finance (e.g., Asbi et al. 2020; Chowk et al. 2016; Greer et al. 2000; Linsky 1975; Ramiah et al. 2014, 2016).

To align the questionnaire with the Covid-19 pandemic in terms of new developments, eleven individuals who are financially affected by the pandemic, academics, and other experts responded to interviews about their perceptions of financial and economic shocks to review the questionnaire's content and vocabulary. Consequently, the questionnaire also included some categories and programs specific to the Covid-19 crisis, as derived from the pilot study (e.g., Covid19 appeal, Community Solidarity Fund against Covid-19, Together We Are Good program). A comprehensive questionnaire was developed and used to collect our final data for the test.

In total, the final questionnaire contained 52 questions. The dependent variable question included 14 items reflecting all categories of losses encountered during Covid-19 and their corresponding recovery time. Regarding the loss variables, respondents provided answers in both financial terms (UAE Dirhams) and using a five-point Likert scale ranging from 1 for no loss to 5 for total loss. As for the recovery variables, we collected data in months. The questionnaire also included fifteen general, categorical questions related to the respondent profile (e.g., sociodemographic, industry, employment status, number of households). The other questions are a combination of Likert scales, open-ended scales, and categorical scales reflecting respondents' evaluations of their retirement plans, pensions, insurances, investments, and other tools to recover from the current pandemic our variables of interest- the bank relief schemes. Finally, the survey included questions related to behavioral biases.

Due to the context of Covid-19, the study used online platforms like SurveyMonkey, LinkedIn, Facebook, WhatsApp, universities portals, and email correspondence to gather the data via snowball sampling. Due to the specific profile of the respondent (i.e., a manager, a household member, or an owner who has incurred a loss during the pandemic), we believe that a snowballing, convenience sample is the best method of identifying participants, according to Sekaran and Bougie (2016)'s recommendations. We have also invited, through email, several UAE residents from our mailing lists (excluding current students) to participate in the study. Some of the emails are straightforward in inviting the 
Table 1 Regression Variables

Dependent variables (Loss): Losses in...

\begin{tabular}{|c|c|c|}
\hline Residential/housing & Business and industry premises & Stocks \\
\hline House contents & Infrastructure and agriculture & Injury \\
\hline Health and psychological impacts & Cultural and heritage & Memorabilia \\
\hline Income & Vehicles & Disruption to business trading \\
\hline Business equipment & Travel and Leisure & \\
\hline \multicolumn{3}{|c|}{ Independent variables (FT): Financial tools } \\
\hline Pension plan & Own investment pool & Retirement planning mechanism \\
\hline Insurance policies & Government grants & Assistance from family and friends \\
\hline Local community assistance & Covid19 appeal & Borrowings \\
\hline Personal reserve fund & Non-profit organization & Stimulus package \\
\hline Bank rent relief package & Mortgage relief package & Personal loan relief package \\
\hline Credit card relief package & SME relief package & Private corporate relief package \\
\hline Community solidarity fund & Together We Are Good & Quarantine period as a \\
\hline against Covid19 & program & savings period \\
\hline Seasonal aspects of the business & $\begin{array}{l}\text { Usage of online technology to generate } \\
\text { income }\end{array}$ & \\
\hline \multicolumn{3}{|l|}{ Demographic variables (Demo): } \\
\hline Sex & Age & Income \\
\hline
\end{tabular}

recipients to participate in the survey. In contrast, another stream of emails requested the recipients to forward the link to other people they suspect have experienced losses from the pandemic. We use similar strategies across all the online platforms we used to increase our response rate and to remain within our budget. Furthermore, we shared our questionnaire with a group of final-year master students at the University of Wollongong in Dubai with the sole purpose of collecting more data. In return, we allow them to use their respective collected data to conduct their analysis related to educational purposes.

The analysis employs the following equation:

$\operatorname{Loss}_{k, i}=\beta_{k, 0}+\sum_{r=1}^{23} \beta_{k, r} * \mathrm{FT}_{k, r, i}+\sum_{n=1}^{3} \beta_{k, n} * \mathrm{Demo}_{k, n, i}+\varepsilon_{k, i}$

The dependent variable captures the variety $(k)$ of losses occurred by any individual $(i)$. We have 14 types; see Table 1. These losses are in UAE Dirhams. The first set of independent variables reflect 23 financial tools, FT, $(r=1, \ldots, 23)$ that we investigate; see the second section in Table 1 . The third section in Table 1 contains the controlled factors in terms of demographics (Demo). ${ }^{23}$

\footnotetext{
$\overline{2}$ See Tables 3 and 4 in the appendix for the summary statistics of the set of dependent and independent variables, respectively.

${ }^{3}$ Note that the losses are subjective values given by the respondents. In case of financial variables, say Income, this is not an issue. Determining the loss in income usually is straightforward. For variables like Health \& psychological impacts, determining the financial losses is much more difficult and highly subjective.
}

The modelling technique used for the above equation is ordinary least squares, as it is the central pillar in contemporary econometrics. We apply diligence to ensure we comply with the classical linear regression function assumptions during the modeling process. For instance, the analysis estimates the statistical behavior of the error terms and parameter values, where necessary. The processes ensure that the model estimated generates heteroscedastic-robust standard errors to guarantee a time/observation-independent variance, using the White-Huber approach. ${ }^{4,5}$

\section{Results and empirical evidence}

The sample includes 446 respondents, including 52\% males, $40 \%$ females, and $8 \%$ who did not disclose their gender. In terms of income, 11\% earn less than AED 3,000 monthly, 28\% from AED 3,001 to AED 10,000, 35\% from AED 10,001 to AED 29,000, 10\% from AED 29,001 to AED 40,000 and 5\% AED 40,001 and above. The total financial losses reported

\footnotetext{
${ }^{4}$ OLS was used to facility comparability with other studies. As a robustness test, the same model was estimating using the method-ofmoments estimation technique. In order to do so, we assumed predeterminedness and the moment condition of non-stochastic covariates. The quantitative and qualitative results remain the same.

5 Table 5 in the appendix contains the same analysis to Sect. "Results and empirical evidence". The only difference is that the dependent variable-loss categories-is specified in log terms. As one can see, the qualitative results remain the same.
} 


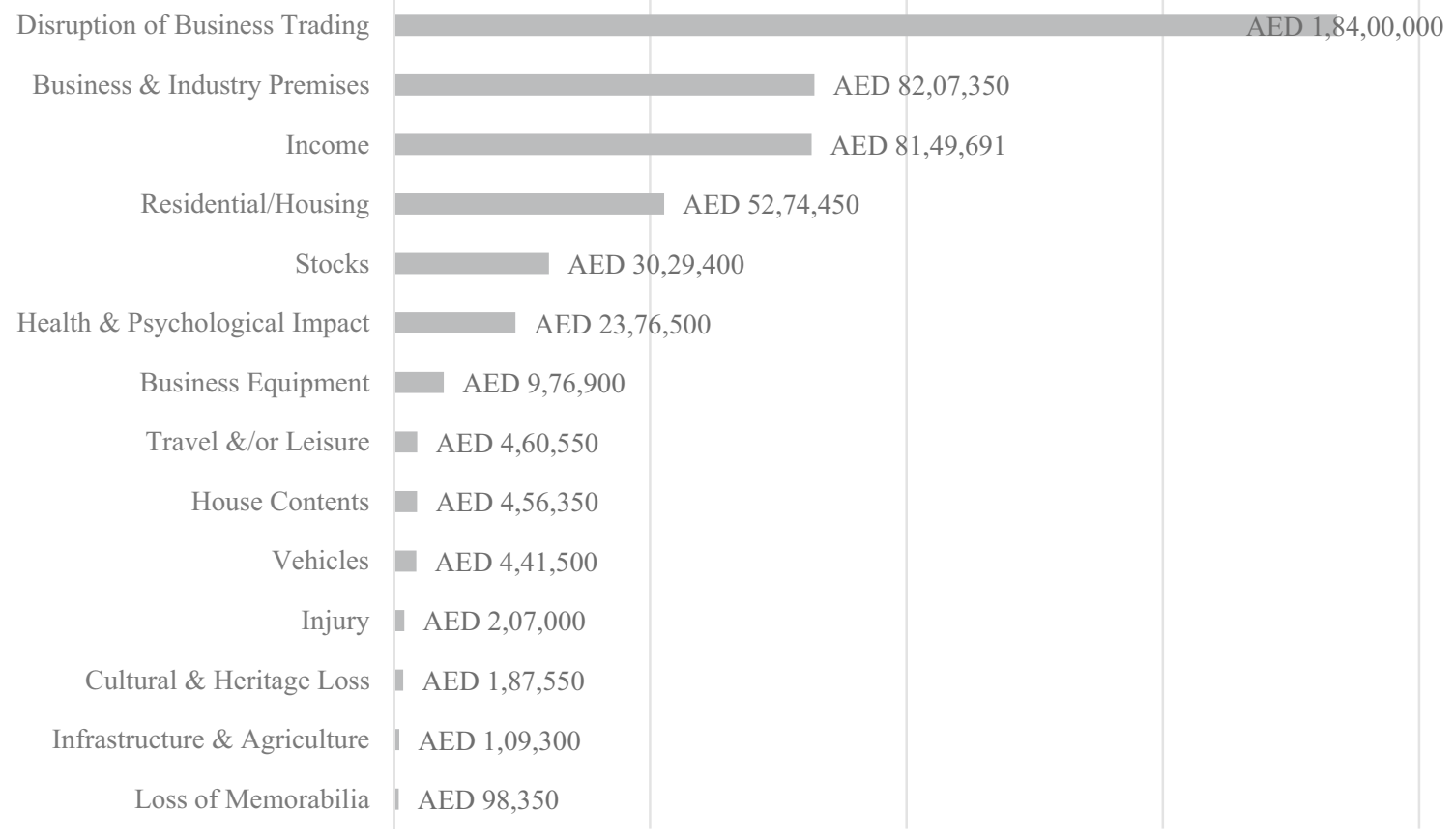

Fig. 1 Losses by category

by the respondents is AED 48,374,891, distributed among 14 categories varying from AED 18,400,000 in business disruptions to AED 98,350 in memorabilia. The distribution of losses among the 14 categories appears in Fig. $1 .^{6}$

The present discussion focuses on newly developed financial tools (stimulus packages, bank rent relief, mortgage relief, personal loan relief, credit card relief, SME relief, and private corporate relief).

\section{CBUAE stimulus package}

As mentioned previously, the CBUAE stimulus package offered to both individuals and corporations has the purpose of facilitating the delivery of temporary relief from the payments of principal and interest on outstanding loans for the private sector corporations, SMEs, and residents.

Our analysis (the second column in Table 2) shows the results of our analysis for this relief scheme. We find a positive and significant relationship for losses in business and industry premises, losses in stocks portfolios, the disruption to business trading, and losses related to travel and leisure. For instance, the coefficient on losses in business and industry premises has a coefficient of 465,652 and a t-statistic of 1.84 .

\footnotetext{
${ }^{6}$ Since monthly income is a flow variable and financial losses is a stock variable, we cannot compare both absolute numbers with each other in order to find the financial burden on income of the respondent. In order to do so, financial wealth, as another stock variable, would need to be found. We thank an anonymous referee for pointing this out.
}

It means that respondents who opted for this relief package on average experienced a higher loss of around AED 465,652 compared to respondents who did not opt for this scheme. We believe that people who experienced higher losses in the value of their business premises from the pandemic opted for the CBUAE stimulus relief package. We find a negative relationship with the loss in the health and psychological impacts, which implies that people who benefited from this package were psychologically relieved. We find no statistical significance for the remaining loss categories-possibly indicating that their losses were not directly related to this scheme but may apply to the other packages we describe below.

\section{Bank rent relief package}

When compared to respondents not accessing the relief package, respondents who opted for the bank rent relief package on average experienced a higher loss of around (1) AED 582,034 for business and industry premises; (2) AED 423,237 for stocks; (3) AED 1,517,088 for disruption to business trading; and, (4) AED 40,846 for travel and leisure. On the other hand, the respondents who selected this option experience a decrease in losses of around AED 506,460 for business equipment.

\section{Mortgage relief package}

We find significant positive relationships between the mortgage relief package and deteriorations in health and 
Table 2 Results-Regression Analysis

\begin{tabular}{|c|c|c|c|c|c|c|c|}
\hline Loss category & $\begin{array}{l}\text { CBUAE } \\
\text { stimulus relief } \\
\text { package }\end{array}$ & $\begin{array}{l}\text { Bank rent relief } \\
\text { package }\end{array}$ & $\begin{array}{l}\text { Mortgage } \\
\text { relief pack- } \\
\text { age }\end{array}$ & $\begin{array}{l}\text { Personal loan } \\
\text { relief package }\end{array}$ & $\begin{array}{l}\text { Credit card } \\
\text { relief pack- } \\
\text { age }\end{array}$ & SME relief package & $\begin{array}{l}\text { Private cor- } \\
\text { porate relief } \\
\text { package }\end{array}$ \\
\hline $\begin{array}{l}\text { Residential/housing } \\
(t \text { stats })\end{array}$ & $\begin{array}{l}69,769 \\
(0.34)\end{array}$ & $\begin{array}{l}323,254 \\
(1.24)\end{array}$ & $\begin{array}{l}208,331 \\
(0.9)\end{array}$ & $\begin{array}{l}-51,011 \\
(-0.33)\end{array}$ & $\begin{array}{l}-53,082 \\
(-0.27)\end{array}$ & $\begin{array}{l}270,828 \\
(0.83)\end{array}$ & $\begin{array}{l}-41,360 \\
(-0.13)\end{array}$ \\
\hline $\begin{array}{l}\text { Business and Indus- } \\
\text { try premises } \\
(t \text { stats })\end{array}$ & $\begin{array}{l}465,652 \\
(1.84 *)\end{array}$ & $\begin{array}{l}582,034 \\
(2.59 * *)\end{array}$ & $\begin{array}{l}307,546 \\
(1.28)\end{array}$ & $\begin{array}{l}-669,617 \\
(-2.67 * * *)\end{array}$ & $\begin{array}{l}478,839 \\
\left(1.85^{*}\right)\end{array}$ & $\begin{array}{l}-115,702 \\
(-0.28)\end{array}$ & $\begin{array}{l}44,129 \\
(0.18)\end{array}$ \\
\hline $\begin{array}{l}\text { Stocks } \\
(t \text { stats })\end{array}$ & $\begin{array}{l}156,380 \\
(4.11 * * *)\end{array}$ & $\begin{array}{l}423,237 \\
(7.29 * * *)\end{array}$ & $\begin{array}{l}23,224 \\
(0.68)\end{array}$ & $\begin{array}{l}-76,290 \\
(-2.16 * *)\end{array}$ & $\begin{array}{l}7,579 \\
(0.24)\end{array}$ & $\begin{array}{l}406,552 \\
(4.99 * * *)\end{array}$ & $\begin{array}{l}-263,358 \\
(-4.65 * * *)\end{array}$ \\
\hline $\begin{array}{l}\text { House contents } \\
(t \text { stats })\end{array}$ & $\begin{array}{l}-4,670 \\
(-0.86)\end{array}$ & $\begin{array}{l}4,077 \\
(0.25)\end{array}$ & $\begin{array}{l}-2,578 \\
(-0.49)\end{array}$ & $\begin{array}{l}775 \\
(0.26)\end{array}$ & $\begin{array}{l}1,510 \\
(0.25)\end{array}$ & $\begin{array}{l}1,111 \\
(0.17)\end{array}$ & $\begin{array}{l}-5,875 \\
(-0.83)\end{array}$ \\
\hline $\begin{array}{l}\text { Infrastructure and } \\
\text { agriculture } \\
(t \text { stats })\end{array}$ & $\begin{array}{l}-734 \\
(-0.43)\end{array}$ & $\begin{array}{l}4,829 \\
(1.06)\end{array}$ & $\begin{array}{l}-2,097 \\
(-1.13)\end{array}$ & $\begin{array}{l}870 \\
(0.41)\end{array}$ & $\begin{array}{l}978 \\
(0.61)\end{array}$ & $\begin{array}{l}107 \\
(0.04)\end{array}$ & $\begin{array}{l}-5,408 \\
(-2.76 * * *)\end{array}$ \\
\hline $\begin{array}{l}\text { Injury } \\
(t \text { stats })\end{array}$ & $\begin{array}{l}-372 \\
(-0.11)\end{array}$ & $\begin{array}{l}4,476 \\
(0.37)\end{array}$ & $\begin{array}{l}-3,697 \\
(-0.76)\end{array}$ & $\begin{array}{l}164 \\
(0.07)\end{array}$ & $\begin{array}{l}1,736 \\
(0.52)\end{array}$ & $\begin{array}{l}-1,493 \\
(-0.19)\end{array}$ & $\begin{array}{l}-2,882 \\
(-0.61)\end{array}$ \\
\hline $\begin{array}{l}\text { Health and psycho- } \\
\text { logical impacts } \\
(t \text { stats })\end{array}$ & $\begin{array}{l}-182,627 \\
(-2.97 * * *)\end{array}$ & $\begin{array}{l}-135,330 \\
(-1.27)\end{array}$ & $\begin{array}{l}197,051 \\
(2.87 * * *)\end{array}$ & $\begin{array}{l}-169,126 \\
(-2.11 * *)\end{array}$ & $\begin{array}{l}47,074 \\
(0.5)\end{array}$ & $\begin{array}{l}118,680 \\
(1.43)\end{array}$ & $\begin{array}{l}16,311 \\
(0.2)\end{array}$ \\
\hline $\begin{array}{l}\text { Cultural and herit- } \\
\text { age loss } \\
(t \text { stats })\end{array}$ & $\begin{array}{l}-3,299 \\
(-0.76)\end{array}$ & $\begin{array}{l}0 \\
(0)\end{array}$ & $\begin{array}{l}-8,259 \\
(-1.67)\end{array}$ & $\begin{array}{l}-3,719 \\
(-0.79)\end{array}$ & $\begin{array}{l}-286 \\
(-0.07)\end{array}$ & $\begin{array}{l}-4,009 \\
(-0.57)\end{array}$ & $\begin{array}{l}-6,930 \\
(-0.75)\end{array}$ \\
\hline $\begin{array}{l}\text { Loss of memorabilia } \\
(t \text { stats })\end{array}$ & $\begin{array}{l}-419 \\
(-0.2)\end{array}$ & $\begin{array}{l}0 \\
(0)\end{array}$ & $\begin{array}{l}-5,937 \\
(-2.84 * * *)\end{array}$ & $\begin{array}{l}-259 \\
(-0.1)\end{array}$ & $\begin{array}{l}-241 \\
(-0.12)\end{array}$ & $\begin{array}{l}-4,008 \\
(-1.31)\end{array}$ & $\begin{array}{l}-2,689 \\
(-0.75)\end{array}$ \\
\hline $\begin{array}{l}\text { Income } \\
(t \text { stats })\end{array}$ & $\begin{array}{l}38,127 \\
(0.76)\end{array}$ & $\begin{array}{l}48,222 \\
(0.74)\end{array}$ & $\begin{array}{l}102,572 \\
(2.11 * *)\end{array}$ & $\begin{array}{l}-68,539 \\
(-2.04 * *)\end{array}$ & $\begin{array}{l}17,365 \\
(0.34)\end{array}$ & $\begin{array}{l}30,404 \\
(0.68)\end{array}$ & $\begin{array}{l}-87,339 \\
(-1.35)\end{array}$ \\
\hline $\begin{array}{l}\text { Vehicles } \\
(t \text { stats })\end{array}$ & $\begin{array}{l}-5,678 \\
(-0.47)\end{array}$ & $\begin{array}{l}-7,419 \\
(-0.28)\end{array}$ & $\begin{array}{l}6,997 \\
(0.73)\end{array}$ & $\begin{array}{l}2,968 \\
(0.46)\end{array}$ & $\begin{array}{l}-5,580 \\
(-0.64)\end{array}$ & $\begin{array}{l}30,161 \\
\left(1.71^{*}\right)\end{array}$ & $\begin{array}{l}-10,692 \\
(-0.92)\end{array}$ \\
\hline $\begin{array}{l}\text { Disruption to busi- } \\
\text { ness trading } \\
(t \text { stats })\end{array}$ & $\begin{array}{l}1,206,587 \\
(2.26 * *)\end{array}$ & $\begin{array}{l}1,517,088 \\
(1.71 *)\end{array}$ & $\begin{array}{l}2,314,036 \\
(3.04 * * *)\end{array}$ & $\begin{array}{l}-375,154 \\
(-0.42)\end{array}$ & $\begin{array}{l}574,033 \\
(0.69)\end{array}$ & $\begin{array}{l}-182,551 \\
(-0.37)\end{array}$ & $\begin{array}{l}2,906,331 \\
(3.51 * * *)\end{array}$ \\
\hline $\begin{array}{l}\text { Business equipment } \\
(t \text { stats })\end{array}$ & $\begin{array}{l}7,613 \\
(0.5)\end{array}$ & $\begin{array}{l}-506,460 \\
(-9.81 * * *)\end{array}$ & $\begin{array}{l}-25,477 \\
(-1.65)\end{array}$ & $\begin{array}{l}23,119 \\
(1.31)\end{array}$ & $\begin{array}{l}9,513 \\
(0.64)\end{array}$ & $\begin{array}{l}-8,588 \\
(-0.36)\end{array}$ & $\begin{array}{l}409,633 \\
(18.02 * * *)\end{array}$ \\
\hline $\begin{array}{l}\text { Travel and leisure } \\
(t \text { stats })\end{array}$ & $\begin{array}{l}16,431 \\
(3.31 * * *)\end{array}$ & $\begin{array}{l}40,846 \\
(6.12 * * *)\end{array}$ & $\begin{array}{l}9,813 \\
\left(1.81^{*}\right)\end{array}$ & $\begin{array}{l}-13,040 \\
(-1.97 *)\end{array}$ & $\begin{array}{l}4,765 \\
(0.78)\end{array}$ & $\begin{array}{l}-4,259 \\
(-0.54)\end{array}$ & $\begin{array}{l}-6,523 \\
(-1.21)\end{array}$ \\
\hline
\end{tabular}

Values in brackets below the coefficient values represent their respective t-statistics

***Significant at a $1 \%$ significance level

**Significant at a $5 \%$ significance level

*Significant at a $10 \%$ significance level

psychological well-being, losses to income, and business trading disruption. Additionally, our empirical model shows a negative relationship between the mortgage relief package and losses in memorabilia and environmental damage (see Table 2). The positive effects are in line with the directives of His Highness Sheikh Mohammed bin Rashid Al Maktoum, Vice-President and Prime Minister of the UAE and Ruler of Dubai, as well as with the instructions of CBUAE to pass on relief to customers following income disruptions such as unpaid leave, loss of jobs, loss of income and other losses related to the pandemic. For example, individual customers ${ }^{7}$ placed on unpaid leave can approach banks for a repayment holiday of up to three months with zero interest and fees. Our results confirm that people who suffered from severe losses from the pandemic could benefit from the mortgage relief package.

\section{Personal loan relief packages}

Those respondents who opted for the personal loan relief package incurred, on average, a more considerable loss for

\footnotetext{
7 Note that first time home buyers benefitted from a 5 percent point increase in the Loan-to-Value ratio and full waiver of processing fees. For a more detailed analysis of how borrowing ratios affect financial markets see Gerth and Temnov (2021).
} 
travel and business. For (1) business \& industry premises; (2) stocks; (3) health and psychological impacts; and (5) income, we find a negative empirical association. This negative relationship between the personal loan relief package and the different loss categories derives from the statistical explanatory power of the CBUAE stimulus package above. If a respondent had considerable losses in his/her business and industry premises, the personal loan relief package would be too small to cover it. In that case, the CBUAE stimulus package would support the respondent's loss. As a result, we find a negative relationship between these high loss categories, see Fig. 1, and the personal loan relief package.

\section{Credit card relief package}

The only statistically robust relationship found for the credit card relief package is with the business and premises loss category. As Table 2 shows, those financially distressed respondents who took advantage of this relief package had on average a higher loss of AED 478,839 in their business and industry premises.

\section{SME relief package}

The SME relief package supported small- and medium-sized enterprises in their business operations during the Covid-19 period. Our empirical analysis shows a positive association with (1) stock portfolios and (2) vehicles. Thus, enterprises that incurred losses either through their financial investments or transport fleet found this relief package helpful.

\section{Private corporate relief packages}

We find a positive relationship between the private corporate relief package and (1) disruption to business trading and (2) business equipment; and a negative relationship to (3) stock portfolios and (4) infrastructure and agriculture. In other words, those respondents who opted for this package had an average disruption of AED 2,906,331 in their business operations and an additional loss of AED 409,633 in their business equipment. Besides, they had a minor loss in their stock portfolios of AED 263,358 and AED 5,408 in infrastructure and agriculture. Consequently, we argue that this program is an addition/extension of the UAE stimulus and the bank relief package.

\section{Concluding remarks}

Our analysis shows that the five most considerable losses incurred by firms and households are to (1) business trading; (2) business and industry premises; (3) income; (4) residential housing; and (5) stock portfolios. These losses amount to a total of more than AED 43mil. Given the restricted sample size, this translates into existential risk for firms and households on a macro-level, potentially harming the very survival of the economic system.

To support large corporations, small- and medium-sized enterprises, and households during the Covid-19 pandemic, regulatory bodies in the UAE enacted numerous public policies. The fiscal and monetary authorities in the UAE have introduced stability tools meant to support the liquidity of the financial system to smooth out any frictions within the real side of the economy. This introduction is effective in its own right; the stimulus package by the CBUAE is a vital determinant in supporting unsustainable losses on the balance sheets of firms and households. For example, our empirical model shows that this monetary policy scheme successfully and directly supports losses in business and industry premises and disruptions to business operations. It also contributes to individuals' psychological and mental well-being that must acknowledge the CBUAE as the lender of last resort. Furthermore, losses in stock portfolios, the short- and long-term savings channel of households, are also supported through this scheme.

In addition to directly supporting the economy, they led to financial intermediaries introducing various products, including relief packages for rent, mortgages, personal loans, credit cards, SMEs, and corporate entities. The objective of each of these tools is the same, screening the financial vulnerability of economic agents. In particular, the bank rent relief package effectively supports firms in their losses to business and industry premises and their disruptions to business operations. Also, the same scheme helps households to smooth out losses in savings put into stock portfolios. Even though it supports firms in their losses to business operations, the mortgage relief package targets and effectively helps private households protect against income loss and threats to mental well-being. The last scheme having a relatively significant and vital role in supporting the economy is the private corporate relief package. Our empirical analysis finds a statistically robust relationship with the disruption to business operations, which implies that firms harmed in their day-to-day business received needed help from this scheme. Besides, this relief package also helped private households in the financial losses of their stock portfolios.

The other three schemes, the personal loan relief package, the credit card relief package, and the SME relief package, surprisingly do not play a significant role in successfully supporting the economy. The authors argue that this is due to several instruments' substitutability, which needs further research.

One surprising finding is that none of these instruments can support households in their losses in residential housing, which is alarming as housing is the most significant part of a household budget. This situation reminds one of the Global Financial Crisis where private individuals were forced to default because mortgages became under-water. The authors suggest that fiscal and monetary policymakers in the UAE 
treat this issue as a high priority and find a way to support homeowners in their debt burden effectively.

Except for residential housing, this article has found that specific policy instruments effectively support the real side of the economy. Further research should focus on a broader sample of stakeholders within the UAE to see whether every stratum of society is supported the same way or whether different tools need to target different parts of the economy. Furthermore, this paper only relies on empirical analysis of the current pandemic; it might be interesting to research the UAE economy's long-run equilibrium effects. Another interesting question might be to analyze the efficiency of the UAE financial system to allocate financial means to the affected stakeholders. Lastly, whereas this study focuses on the losses incurred due to the Covid-19 pandemic, some savers and investors gained. It would be interesting to see how financial gains counteract financial losses to analyze the welfare effect. We leave these limitations and considerations for further research.

The findings of this paper have both academic and practical implications in that we show that stimulus packages are valuable financial instruments for government to use to recover from crises.

\section{Appendix}

See Tables 3, 4, 5 .
Table 4 Financial Recovery Tools

Independent Variables (FT): Financial tools

\begin{tabular}{lll}
\hline & Yes & No \\
\hline Pension plan & 56 & 390 \\
Own investment pool & 155 & 291 \\
Retirement planning mechanism & 20 & 426 \\
Insurance policies & 63 & 383 \\
Assistance from family and friends & 144 & 302 \\
Government grants & 45 & 401 \\
Local community assistance & 27 & 419 \\
Covid-19 appeal & 11 & 435 \\
Borrowings & 26 & 420 \\
Personal reserve fund & 93 & 353 \\
Non-profit organization & 14 & 432 \\
Stimulus package & 17 & 429 \\
Bank rent relief package & 20 & 426 \\
Mortgage relief package & 23 & 423 \\
Personal loan relief package & 41 & 405 \\
Credit card relief package & 19 & 427 \\
SME relief package & 24 & 422 \\
Private corporate relief package & 11 & 435 \\
Community solidarity fund against Covid-19 & 6 & 440 \\
Together We Are Good program & 51 & 395 \\
Quarantine period as a savings period & 52 & 394 \\
Seasonal aspects of the business & 13 & 433 \\
Usage of online technology to generate income & 34 & 412 \\
\hline
\end{tabular}

Table 3 Summary StatisticsFinancial Losses (UAE Dirham)

\begin{tabular}{lrrrrrr}
\hline Dependent variables (Loss): Losses in... & \multicolumn{1}{c}{ Median } & Std Dev & Min & \multicolumn{1}{c}{ Max } \\
\hline & $N$ & \multicolumn{1}{c}{ Mean } & Mencen \\
\hline Residential/housing & 108 & 48,838 & 4000 & $3,03,175$ & 0 & $3,000,000$ \\
Business and industry premises & 89 & 92,217 & 3250 & $3,60,119$ & 0 & $2,500,000$ \\
Stocks & 89 & 34,038 & 2500 & $1,35,999$ & 0 & $1,000,000$ \\
House contents & 85 & 5369 & 2500 & 7888 & 0 & 45,000 \\
Infrastructure and agriculture & 68 & 1607 & 0 & 2481 & 0 & 15,000 \\
Injury & 70 & 2957 & 500 & 5186 & 0 & 35,000 \\
Health and psychological impacts & 91 & 26,115 & 5000 & $1,09,003$ & 0 & $10,00,000$ \\
Cultural and heritage & 61 & 3075 & 0 & 4018 & 0 & 12,500 \\
Memorabilia and environment & 71 & 2561 & 0 & 2222 & 0 & 15,000 \\
Income & 178 & 45,785 & 10,000 & $1,62,632$ & 0 & $2,000,000$ \\
Vehicles & 83 & 5319 & 2000 & 9553 & 0 & 60,000 \\
Disruption to business trading & 77 & 238,313 & 1500 & $10,15,399$ & 0 & $60,00,000$ \\
Business equipment & 71 & 13,759 & 0 & 50,332 & 0 & 400,000 \\
Travel and leisure & 86 & 5355 & 2725 & 11,607 & 0 & 80,000 \\
\hline
\end{tabular}




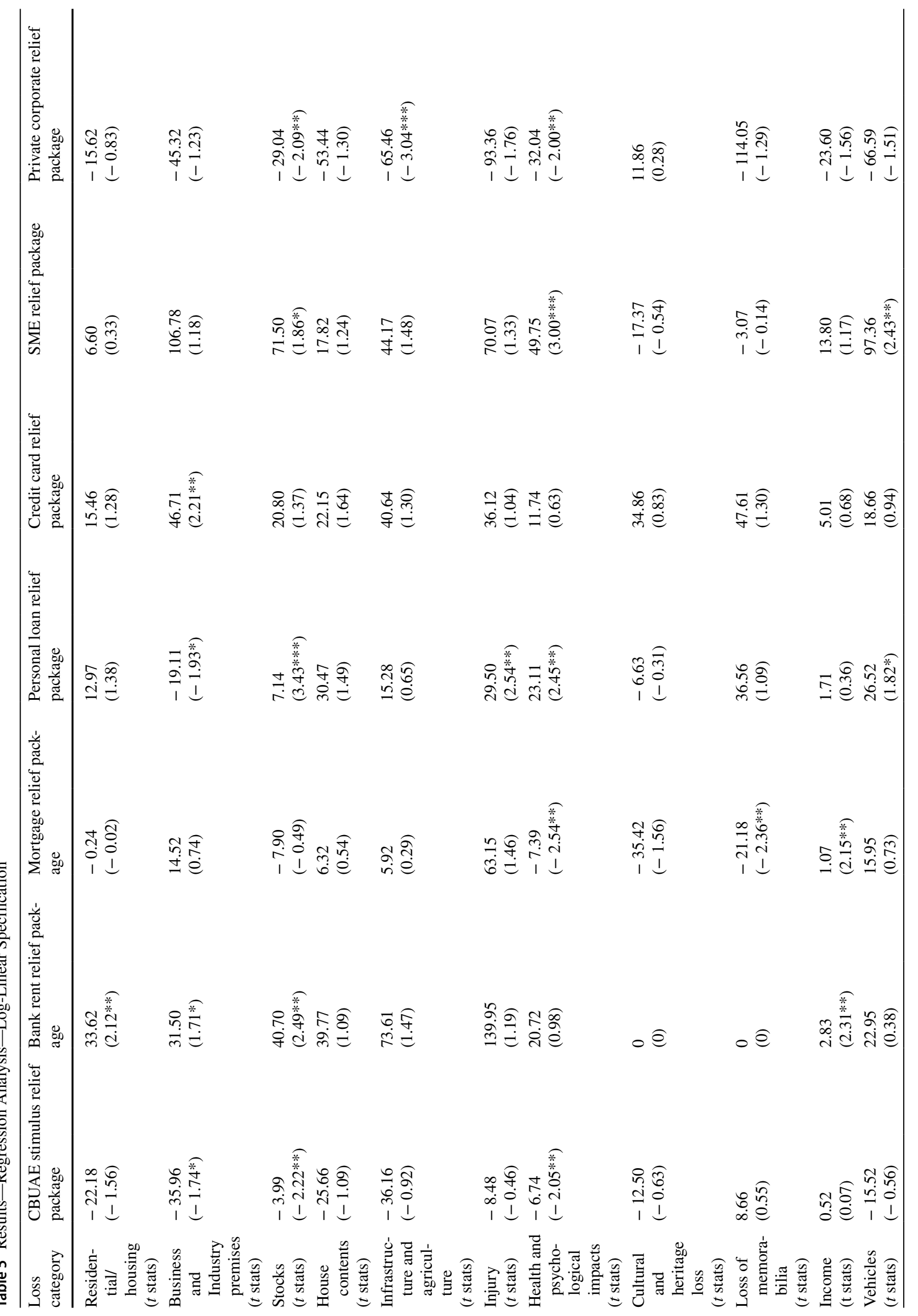




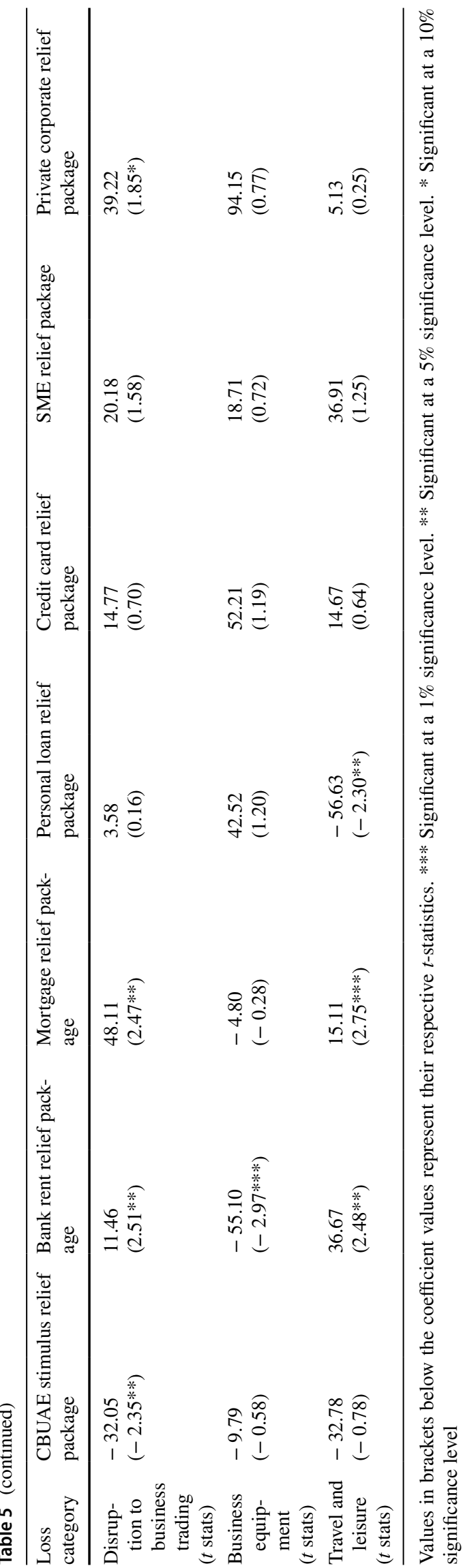

Supplementary Information The online version contains supplementary material available at https://doi.org/10.1057/s41264-021-00098-w.

\section{References}

Asbi, A., V. Ramiah, X. Yu, D. Wallace, N. Moosa, and K. Reddy. 2020. The determinants of recovery from the Black Saturday bushfire: demographic factors, behavioural characteristics and financial literacy. Accounting and Finance 60 (1): 15-46.

Arabian Business (2020), Dubai Chamber donates $\$ 2.7 \mathrm{~m}$ to coronavirus solidarity fund, https://www.arabianbusiness.com/healt hcare/444339-dubai-chamber-donates-27m-to-coronavirus-solid arity-fund, accessed June 2020

Bezhani, I. 2010. Intellectual capital reporting at UK universities. Journal of Intellectual Capital 11 (2): 179-207.

Brown, K. (2020) The pandemic is not a natural disaster: the coronavirus isn't just a public-health crisis. It's an ecological one. New Yorker, 13 April, https://www.newyorker.com/culture/annalsof-inquiry/the-pandemic-is-not-a-natural-disaster, accessed 24 November 2020.

Brown, R., A. Rocha, and M. Cowling. 2020. Financing entrepreneurship in times of crisis: Exploring the impact of COVID-19 on the market for entrepreneurial finance in the United Kingdom. International Small Business Journal: Researching Entrepreneurship 38 (5): 380-390.

Chowk, G., Ramiah, V., I. and Moosa, I. (2016) Behavioural biases of Australian financial planners. Paper presented at the 23rd Annual Conference of the Multinational Finance Society; 26-29 June, Stockholm, Sweden.

Corbet, S., C. Larkin, and B. Lucey. 2020. The contagion effects of the COVID-19 pandemic: evidence from gold and cyptocurrencies. Finance Research Letters 35: 1-7.

Cowling, M., R. Brown, and A. Rocha. 2020. Did you save some cash for a rainy COVID-19 day? The crisis and SMEs. International Small Business Journal: Researching Entrepreneurship 38 (7): 593-604.

Elnahass, M., V.Q. Trinh, and T. Li. 2021. Global banking stability in the shadow of Covid-19 outbreak. Journal of International Financial Markets, Institutions and Money 72: 1-32.

Finsterwalder, J., and V.G. Kuppelwieser. 2020. Equilibrating resources and challenges during crises: a framework for service ecosystem well-being. Journal of Service Management 31 (6): 1107-1129.

Galea, S., M. Tracy, F. Norris, and S.F. Coffey. 2008. Financial and social circumstances and the incidence and course of PTSD in Mississippi during the first two years after Hurricane Katrina. Journal of Traumatic Stress 21 (4): 357-368.

Gerth, F., and G. Temnov. 2021. New ways of modeling loan-to-income distributions and their evolution in time-A probability copula approach. International Review of Economics \& Finance 71: 217-236.

Greene, F.J., and A. Rosiello. 2020. A commentary on the impacts of "Great Lockdown" and its aftermath on scaling firms: what are the implications for entrepreneurial research? International Small Business Journal: Researching Entrepreneurship 38 (7): 583-592.

Greer, T.V., R. Chuchinprakarn, and S. Seshadri. 2000. Likelihood of participating in mail survey research: business respondents' perspectives. Industrial Marketing Management 29 (2): 97-109.

Hall, M., G. Prayag, and P. Fieger. 2020. Beyond panic buying: consumption displacement and COVID-19. Journal of Service Management. https://doi.org/10.1108/JOSM-05-2020-0151.

Heinonen, K., and T. Strandvik. 2020. Reframing service innovation: COVID-19 as catalyst for imposed service innovation. 
Journal of Service Management. https://doi.org/10.1108/ JOSM-05-2020-0161.

Hepburn, C., B. O'Callaghan, N. Stern, J. Stiglitz, and D. Zenghelis. 2020. Will COVID-19 fiscal recovery packages accelerate or retard progress on climate change? Oxford Review of Economic Policy 36 (S1): S359-S381.

KPMG. (2020) United Arab Emirates: government and institution measures in response to COVID-19. KPMG report, 18 November, https://home.kpmg/xx/en/home/insights/2020/04/united-arabemirates-government-and-institution-measures-in-response-tocovid.html, accessed 1 December 2020).

Linsky, A.S. 1975. stimulating responses to mailed questionnaires: a review. Public Opinion Quarterly 39 (1): 82-102.

Pandey, N. 2021. Digital marketing strategies for firms in post covid-19 era: insights and future directions. In The new normal challenges of managerial business, social and ecological systems in the post covid-19 era, ed. H. Chaturvedi and A.K. Dey. New Delhi: Bloomsbury Prime.

Pew Charitable Trusts. (2015) The role of emergency savings in family financial security: how do families cope with financial shocks? Pew Charitable Trusts repot, October, https://www.pewtrusts.org/ /media/assets/2015/10/emergency-savings-report-1_artfinal.pdf, accessed 12 December 2020.

Ramiah, V., Y.L. Zhao, and I. Moosa. 2014. Working capital management during the global financial crisis: the Australian experience. Qualitative Research in Financial Markets 6 (3): 332-351.

Ramiah, V., Y.L. Zhao, I. Moosa, and M. Graham. 2016. A behavioural finance approach to working capital management. European Journal of Finance 22 (8-9): 662-687.
Ritcher, A., and T. Wilson. 2020. Covid-19: implications for insurer risk management and the insurability of pandemic risk. The Geneva Risk and Insurance Review 45: 171-199.

Sekaran, U., and R. Bougie. 2016. Research methods for business: a skill-building approach. New York: Wiley.

Statista Research Department. (2020) Impact of the coronavirus pandemic on the global economy - statistics \& facts. Statista Research Department report, 20 November, https://www.statista.com/topics/6139/covid-19-impact-on-the-global-economy/, accessed 1 December 2020.

UAE Government Portal. (2020) Economic support to minimize the impact of COVID-19. UAE Government report, https://u.ae/en/ information-and-services/justice-safety-and-the-law/handling-thecovid-19-outbreak/economic-support-to-minimise-the-impact-ofcovid-19, accessed 1 December 2020.

United Nations Office for Disaster Risk Reduction. (2012) Disaster risk and resilience, United Nations report, May, https://www.un.org/ en/development/desa/policy/untaskteam_undf/thinkpieces/3_disas ter_risk_resilience.pdf, accessed 24 November 2020.

Zhang, Z., and W. Zhang. 2011. The road to recovery: fiscal stimulus, financial sector rehabilitation, and potential risks ahead. Journal of Asian Economics 22 (4): 311-321.

Publisher's Note Springer Nature remains neutral with regard to jurisdictional claims in published maps and institutional affiliations. 